\title{
Extension
}

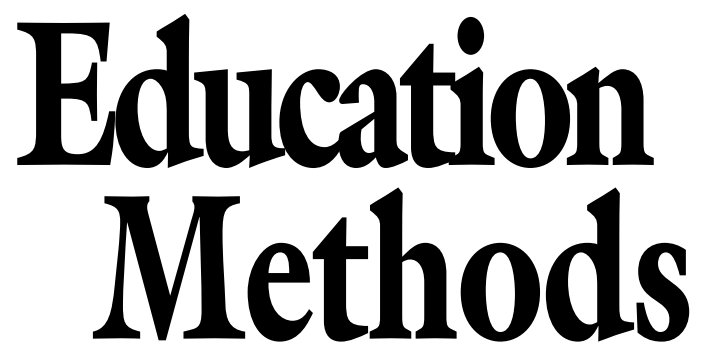

\section{Using On-farm \\ Demonstrations to Promote Integrated Pest Management Practices in Tomato Production}

\author{
Edward J. Sikora, ${ }^{1}$ Joseph. M. Kemble, ${ }^{2}$ \\ Goeff W. Zehnder, ${ }^{3}$ W. Robert Goodman, ${ }^{4}$ \\ Mahefatiana Andrianifahanana, ${ }^{5}$ \\ Ellen M. Bauske, ${ }^{6}$ and John F. Murphy ${ }^{1}$
}

Additional INDEX wORds. Franklinella occindentalis, western flower thrips, Helicoverpa zea, tomato fruitworm, IPM, scouting, TOM-CAST, Alternaria solani, early blight, Tomato spotted wilt virus, TSWV

Summary. The Alabama Tomato Integrated Pest Management (IPM) Program was demonstrated during two growing seasons in southeastern Alabama. The program consisted of a twice-a-week insect/disease scouting service combined with a weather-timed spray program (TOMCAST). On average, growers made four fewer insecticide applications and three to four fewer fungicide applications when following the IPM program compared to their conventional, calendar-based program. There was no apparent

\footnotetext{
${ }^{1}$ Associate professor, Department of Entomology and Plant Pathology, 105 Extension Hall, Auburn University, AL 36849-5624; esikora@acesag.auburn.edu.

${ }^{2}$ Associate professor, Department of Horticulture, Auburn University, AL 36830. ${ }^{3}$ Former professor, Department of Entomology and Plant Pathology, Auburn Uni versity, AL 36849-5624.

${ }^{4}$ Associate professor, Department of Agricultural Economics and Rural Sociology, Auburn University, AL 36830.

${ }^{5}$ Former extension associate, Department of Entomology and Plant Pathology, Auburn University, AL 36830.

${ }^{6}$ Executive vice president, Agricultural Weather Information Service, P.O. Box 3267 Auburn, AL 36830
}

reduction in yield when following the IPM program. An economic analysis indicated that growers following the IPM program saved an average of $\$ 54.36 /$ acre $(\$ 134.32 /$ ha $)$.

$\mathrm{F}$ resh-market tomatoes (Lycopersicon esculentum) are an important crop in Alabama with an estimated value of $\$ 18$ million. Several plant diseases and insect pests significantly affect tomato production in the state. Attempts by growers to control these pests often result in extensive use of pesticides. This is problematic, as consumers have expressed increasing concern over the use of pesticides in food production. In addition, economical management techniques are needed to maintain profitability. One way for growers to reduce pesticide usage while maintaining profitability is to incorporate IPM strategies into their production program. IPM is a sustainable approach to managing pests by combining biological, cultural, physical, and chemical tools in a way that minimizes economic, health and environmental risks (National Coalition of Integrated Pest Management, 1994).

The ubiquitous tomato fruitworm (Helicoverpa zea) feeds directly on tomato fruit, which reduces marketable yields. To prevent fruitworm damage, many tomato growers spray synthetic insecticides (e.g., esfenvalerate) on a weekly or more-frequent schedule. Often, growers include an insecticide with their fungicide applications (tank-mix) as an insurance measure to protect against fruitworm damage, regardless of whether an insecticide application is actually needed. This practice of calendar-based (weekly) insecticidal spraying results in increased production costs, destroys natural enemies of the tomato fruitworm (Campbell et al., 1991), and can result in greater insecticide residues on the tomato fruit (Spittler et al., 1984) and in the environment. Experiments conducted in Alabama demonstrated that insecticides applied only when fruitworm eggs were detected on tomato foliage provided the same protection as calendar-based sprays (Zehnder et al., $1995)$. Although tomato fruitworm is a key economic pest of tomato in Alabama and the southern U.S., other pests can cause damage and should be included in scouting programs. These include beet armyworm (Spodoptera exigua), flower thrips (Frankliniella sp.), tomato pinworm (Keiferia lycopersicella) and several species of stink bugs (Pentatomidae) and aphids (Aphididae). Thresholds for these insects were developed in Florida (Pernezny et al., 1995) and modified for use in Alabama.

TOMCAST is a weather-based fungicide spray program for control of early blight (Alternaria solani), septoria leaf spot (Septoria lycopersica) and anthracnose (Colletotrichum coccodes) (Pitblado, 1992). TOMCAST had previously been tested in Alabama and was shown to be effective and economical for use on fresh-market tomatoes (Sikora et al., 1994a, 1994b). TOMCAST does not predict bacterial or viral diseases, or any other fungal diseases, which is why a disease scouting program must accompany it. Typically, data loggers, such as Campbell Scientific's (Logan, Utah) model CRl0, are placed near tomato fields where they record leaf wetness and temperature on an hourly basis. Every $24 \mathrm{~h}$ these data are analyzed and converted to a disease severity value (DSV). DSVs are added from day to day until they exceed a predetermined threshold, which triggers a recommendation to apply a fungicide. Given appropriate data inputs, DSVs can be accurately estimated by private weather services (Sikora, unpublished). 
In 1996, a survey was conducted to determine the levels of adoption of tomato IPM in Alabama, Georgia, Kentucky, North Carolina, northern Florida, South Carolina and Tennessee (Bauske et al., 1998). The results of this survey indicated that $65 \%$ of the Alabama growers used IPM practices regularly. Though several of the survey respondents in Alabama said they used insect and disease scouting, they had little or no training for this task. No trained scouts were working with these growers nor had any of the growers surveyed in Alabama used TOMCAST. These facts suggested that efforts to increase scouting and the use of TOMCAST would greatly increase the level of IPM use in Alabama.

Alabama growers were interested in adopting insect and disease scouting and TOMCAST strategies. However, they expressed concern about the increase traffic over the field and the physical and economic constraints of applying fungicides and insecticides independently on an "as needed" basis. They questioned if it was feasible to integrate the two programs. More importantly, would there be a financial gain associated with the extra work? To address these issues, large scale, onfarm field demonstrations were established in the southeastern tomato production region of the state in 1997 and 1998 to compare the Alabama Tomato IPM Program with conventional management practices currently used by growers.

\section{Materials and Methods}

The demonstrations were conducted in Geneva County, Ala. Three growers participated in the demonstrations in 1997 and four participated in 1998. Each grower set aside a one acre (0.40 ha) tomato field for the purpose of comparing the Alabama Tomato IPM Program with conventional, pest management practices following calendar-based pesticide applications. Each grower followed conventional pest management practices on half of the field and the IPM program outlined by Auburn University on the other half. The IPM program consisted of a twice-a-week insect/disease scouting program combined with TOMCAST.

For insect control in the conventional field sections growers typically applied weekly sprays of dimethoate (Cygon; BASF, Research Triangle Park, N.C.) or esfenvalerate (Asana XL; E.I. du Pont de Nemours and Co., Wilmington, Del.) alone or in combination. Dimethoate was applied season long or through mid-season only, depending on the grower, for control of aphids and thrips. Esfenvalerate was applied season long or from mid-season through harvest for control of armyworm and fruitworm. Some of the growers made one application of methomyl (Lannate; du Pont) near the end of the season for beet armyworm control. Rates varied depending on the grower and time of season.

For disease control in the conventional field section growers typically applied a weekly tank-mix of a protectanttype fungicide such as mancozeb (Manzate 200 DF; du Pont, or Dithane DF; Rohm and Haas Co., Philadelphia, Pa.) or chlorothalonil (Bravo 720; Zeneca Ag Products, Wilmington, Del.) plus a copper hydroxide-containing material (Kocide 101; Griffin, LLC, Valdosta, Ga.), or a prepackaged tank-mix formulation of mancozeb plus copper hydroxide (ManKocide; Griffin, LLC) or chlorothalonil plus copper oxychloride plus maneb (Bravo C/M; ISK Biosciences Corp., Mentor, Ohio) beginning shortly after transplanting. Rates of the various formulations varied depending on the grower and time of season.

IPM field sections were visited twice weekly by the scout beginning the first week after transplanting (late March) and continuing through the end of harvest (mid-July). The scout would make a general visual inspection of the entire field for any signs of diseaseincidence. The scout would then examine 50 plants ( 5 plants at 10 randomly selected locations) within the 0.5 -acre (0.2 ha) IPM field section. At each location, the scout would first make a visual inspection for flying insects. He would then examine the first fully expanded leaf and all new foliage for aphids, thrips, whiteflies (Aleyrodidae), and eggs of tomato fruitworm. The lower foliage was then inspected for armyworm and loopers (Trichoplusia ni), and the whole plant was examined for stinkbugs. After anthesis, one flower/plant was inspected for thrips. After fruit set, two fruit/plant were inspected for damage from fruitworm, thrips or stinkbugs. The insect density for each species per unit (flower/plant) was averaged for each field section and compared to the action threshold levels (Table 1) used to determine insecticide spray recommendations. A written report was submitted to the grower after each scouting session with information on pest incidence and a pesticide recommendation if pest thresholds were exceeded.

Table 1. Treatment thresholds utilized for management of insect pests on fresh-market tomato in the integrated pest management (IPM) field section, adapted from Pernezny et al. (1995).

\begin{tabular}{|c|c|c|}
\hline Pest & Cropstage & Threshold \\
\hline Aphids & Season long & $>3-4 /$ plant \\
\hline Armyworms & Prebloom & 1 larva/5 plants \\
\hline Postbloom & & 1 egg or larva/field \\
\hline Fruitworms & Prebloom & 1 larva/2 plants \\
\hline Postbloom & & 1 egg or larvae per field \\
\hline Stinkbugs & Postbloom & 1 insect $/ 5$ plants \\
\hline Thrips & Postbloom & $>5 /$ flower \\
\hline
\end{tabular}

Table 2. Comparison of the average number of insecticide applications in the conventional and integrated pest management (IPM) field sections of the seven grower cooperators in 1997 and 1998.

\begin{tabular}{lccc}
\hline & \multicolumn{3}{c}{ Avg no. applications/season $^{\mathbf{z}}$} \\
\cline { 2 - 4 } Year $^{\mathbf{y}}$ & Conventional & IPM & Difference \\
\hline 1997 & 14.3 & 9.3 & 5.0 \\
1998 & 9.0 & 5.8 & 3.2 \\
Average & 11.2 & 7.5 & 3.7 \\
\hline
\end{tabular}

${ }^{\mathrm{z}}$ Average from three demonstration sites in 1997 and four demonstration sites in 1998.

'Insecticides used varied by grower and included: dimethoate, esfenvalerate, lambdacyhalothrin and methomyl.

Table 3. Comparison of the average number of fungicide applications for foliar disease control in the conventional and integrated pest management (IPM) field sections of the seven grower cooperators in 1997 and 1998.

\begin{tabular}{lccc}
\hline & \multicolumn{3}{c}{ Avgno. applications/season $^{\mathbf{z}}$} \\
\cline { 2 - 4 } Year $^{\mathbf{y}}$ & Conventional & IPM & Difference \\
\hline 1997 & 15.0 & 10.6 & 4.4 \\
1998 & 10.5 & 7.5 & 3.0 \\
Average & 12.4 & 8.8 & 3.4 \\
\hline
\end{tabular}

${ }^{\mathrm{z}}$ Average from three demonstration sites in 1997 and four demonstration sites in 1998.

'Fungicides used varied by grower and included: chlorothalonil, chlorothalonil plus copper oxychloride plus maneb, copper hydroxide, mancozeb, mancozeb plus copper hydroxide and mefenoxam plus chlorothalonil. 
In the IPM field sections, farmer cooperators began the season with a weekly tank-mix of mancozeb or chlorothalonil plus a copper hydroxide-containing material, or a prepackaged tank-mix formulation of mancozeb plus copper hydroxide beginning $3 \mathrm{~d}$ after transplanting. Rates of the various formulations varied depending on the grower. Following the third fungicide application, growers would then make subsequent applications on 14-d intervals unless more frequent applications were recommended by TOMCAST. TOMCAST DSVs for each demonstration site were monitored by an extension specialist at Auburn University who would telephone the grower to recommend a fungicide application when the accumulated DSVs reached the predetermined threshold. DSVs were estimated from a gridded model output by AWIS Weather Services Inc. (AWIS), a private weather information company located in Auburn, Ala. This method had been tested previously and provided reasonable estimates of DSVs (E. Sikora, unpublished). Because TOMCAST has been validated for a relatively narrow range of fungal pathogens, other diseases such as late blight (Phytophthora infestans) and bacterial spot (Xanthomonas axonopodis pv. vesicatoria) can cause considerable damage if undetected while following the TOMCAST program. Early detection of these diseases through scouting allowed us to adjust the grower's spray program accordingly.

Observations on the incidence and severity of plant diseases were made at each of the 10 locations within each IPM field section. If the scout detected late blight or bacterial spot, the grower was advised to discontinue the TOMCAST program and initiate a weekly spray program with the appropriate fungicide and/or bactericide.

At the end of the season, the number of pesticide applications used in the conventional and IPM programs were totaled, and an economic analysis was performed. Normal expenses and returns were calculated and potential profits identified for each program. Actual expenses incurred for both systems were averaged across growers and years. Variable costs of application included gas, oil, water, tires, labor, insurance and other expenses needed for applying pesticides. The cost of scouting was set at $\$ 15.00 /$ acre $(\$ 37.06 / \mathrm{ha})$ based on an estimate given by a scouting service in Alabama.

\section{Results}

On average, growers made four fewer insecticide applications when following the IPM program compared to their conventional program over the 2-year period (Table 2). Thrips-transmitted tomato spotted wilt virus (TSWV) was the most significant problem to develop during the demonstrations. Western flower thrips (Franklinella occindentalis) was the predominant thrips species, and their feeding also resulted in fruit damage. Populations of thrips reached or exceeded treatment threshold levels in IPM field sections on all seven farms. A dimethoate application was recommended in each case and growers applied the material an average of 4.8 times with a range of 2 to 8 applications. Growers applied an average of 9.7 dimethoate sprays in the conventional field sections with a range of 7 to 15 applications in both years.

Fruitworm populations reached or exceeded treatment thresholds in IPM field sections of all seven farms. An esfenvalerate application was recommended in each case and growers applied the material an average of 3.5 times with a range of 2 to 6 applications. Growers applied an average of 8.8 esfenvalerate sprays in the conventional field sections with a range of 7 to 15 applications.

Stinkbugs were the only other insect pest observed above threshold levels in any of the IPM field sections. An application of lambda-cyhalothrin (Karate; Zeneca Ag Products) was recommended by the scout on one farm in 1997. The grower also made one lambda-cyhalothrin application in his conventional field section, apparently in response to our IPM recommendation. Three of the seven cooperators made one application of methomyl near the end of the season for armyworm control. Armyworms never reached action threshold levels in the IPM field sections.

On average, growers made three to four fewer fungicide applications when following the IPM program compared to their conventional program (Table 3 ). Growers made an average of 8.8 fungicide applications in the IPM field section with a range of 6 to 13 sprays. Growers averaged 12.4 fungicide applications in the conventional field sections with a range of 9 to 19 sprays.

Severity of early blight was estimated at less then $1 \%$ in all conventional and IPM field sections near the end of harvest in both years. Two of the three cooperators in 1997 discontinued the TOMCAST program at midseason; one because of an outbreak of bacterial spot and the other because of the appearance of late blight. Each disease was observed in both the conventional and IPM field sections for each grower. The scout recommended weekly sprays of mancozeb plus copper hydroxide for the field with bacterial spot and mefenoxam plus chlorothalonil (Ridomil Gold/Bravo; Novartis, Greensboro, N.C.) for the field with late blight. Thereafter, neither disease developed into a significant problem. An economic analysis of the data indicated that the IPM program sections saved an average of $\$ 54.36 /$ acre $(\$ 134.32 /$ ha $)$ (Table 4$)$, with a range in savings of $\$ 7.63$ to $\$ 215.63$ per acre $(\$ 18.85$ to $\$ 532.81$ per ha) among growers (data not shown). Based on these numbers, a grower of an averaged sized tomato farm in

Table 4. Economic analysis of the conventional program versus the integrated pest management (IPM) program on a 22 acres (8.9 ha) tomato farm (average size tomato farm in Alabama) and on a per-acre $(0.40 \mathrm{ha})$ basis.

\begin{tabular}{llll}
\hline & Conventional & IPM & Cost differential \\
\cline { 2 - 4 } Costs & & $\mathbf{\$ / 2 2}$ acres (\$/acre) & \\
\hline Variable cost of application $^{\mathrm{y}}$ & $743.82(33.81)$ & $735.24(33.42)$ & $8.58(0.39)$ \\
Insecticides & $1734.48(78.84)$ & $903.54(41.07)$ & $830.94(37.77)$ \\
Fungicides & $2920.50(132.75)$ & $2129.16(96.78)$ & $791.34(35.97)$ \\
Scouting service & 0.00 & $330.00(15.00)$ & $-330.00(-15.00)$ \\
TOMCAST program & & $105.00(4.77)$ & $-105.00(-4.77)$ \\
Total cost & 0.00 & $4202.94(191.04)$ & $1195.86(54.36)$ \\
\hline
\end{tabular}

${ }^{\mathrm{z}} \$ 1.00$ acre $=\$ 2.47 \mathrm{ha}$

yncludes cost of gas, oil, water, tires, labor, insurance and other items needed for applying pesticides.

${ }^{x}$ The cost of TOMCAST and the scouting service is based on a 12 week growing season. 
Alabama [22 acres (8.8 ha)] would have saved \$1,195.86 following the IPM program. The savings were based on a $47 \%$ reduction in the cost of insecticides, and a $27 \%$ reduction in the cost of fungicides, when cooperators followed the IPM program. Growers following the IPM program made a comparable number of trips through their fields (12.4) to apply pesticides as the conventional program (12.8).

\section{Discussion}

Significant differences in weather and pest pressures between the 2 years provided a vigorous test of the Alabama IPM Program. More fungicide applications were made in both the conventional and IPM programs in 1997 than in 1998 (Table 3). This was due to relatively dry conditions in 1998, which were less favorable for disease development. The TOMCAST program worked as well as the conventional fungicide spray program in managing early blight under these diverse environmental conditions.

TOMCAST must be used in conjunction with a scouting program in Alabama due to the variety of bacterial and fungal diseases that can occur in any given year. In 1997, the scout identified bacterial spot and late blight in IPM fields, which allowed for a rapid response by the growers. Without the scouting service, damage from either disease could have been extensive.

More insecticides were applied in both the conventional and IPM field sections in 1997 than in 1998. This was due to high populations of thrips at all three demonstration sites in 1997, often above threshold levels, which resulted in frequent applications of dimethoate in the IPM sections. The reduction in insecticide applications in 1998 in both the conventional and IPM sections was in response to lower thrips populations and grower confidence in the field scout's recommendations. Prior to the second year of this project, growers in the area typically applied a tank-mix of dimethoate and esfenvalerate weekly for control of aphids and fruitworms, regardless if the insects were observed in their fields. Clearly, growers became more confident with our IPM recommendations in the second year. We believe this trust prompted them to reduce their reliance on pesticide inputs in their conventional program in 1998. This may have biased the economic analysis presented here, causing an underestimation of the benefits of the IPM program.

The growers were incorrect in their assumption that the integration of field scouting for insects with TOMCAST would increase the number of trips across the field relative to a management program based on scheduled pesticide applications. Growers were contacted only when DSVs reached the predetermined threshold level requiring a fungicide application. Therefore, the growers had no prior notice of the estimated timing of their fungicide applications. If the growers had direct access via the Internet to the accumulated DSVs, it would have provided them an opportunity to combine an insecticide and fungicide in one application when both are recommended. This would have eliminated the need for separate trips across the field reducing the total number of applications necessary, and the total cost of the management program. Although use of computers in farming operations is still infrequent in Alabama, use of computer technology is growing. According to a "Farm Computer Usage and Ownership" survey conducted by the National Agricultural Statistics Service in 2001, the number of farms in Alabama that use computers in their farm business increased from 13 to $24 \%$ from 1997 to 2001 (USDA, 2001).

The general consensus among growers participating in this project was that the IPM program was worth the additional effort. All the cooperators indicated no apparent difference in yield between the conventional and IPM field sections, though yield data were not available. All the growers who participated in this project saved money on pesticides; growers on average saved $\$ 54.00$ /acre following the IPM program. Growers had a favorable opinion of the scouting program and indicated they would be willing to pay for such a service. One scouting service in Alabama fixed a price of \$15.00/acre to scout tomatoes, though prices vary widely throughout the country.

TOMCAST was also viewed favorably, though growers indicated they would prefer accessing the information directly. TOMCAST can be delivered via fax or the Internet by AWIS. A grower would need to purchase TOMCAST for 3 months in order to cover a full season (12 weeks) in Alabama. AWIS has a set fee of $\$ 35$ per month for TOMCAST for any location, regardless of the size of the farm operation. Therefore, the cost of TOMCAST on a per acre basis decreases with increasing acreage. The average size for a commercial tomato farm in Alabama is 22 acres, which would result in a cost of $\$ 4.77 /$ acre (\$11.79/ha) for TOMCAST for a 3 -month period (Table 4).

This project successfully provided the growers of Alabama with a clear vision of the benefits of a tomato IPM program. Scouting combined with TOMCAST provided effective pest control, was economically advantageous, and did not adversely increase the workload on the producers.

\section{Literature cited}

Bauske, M, G.M. Zehnder, E.J. Sikora, and J. Kemble. 1998. Southeastern tomato growers adopt integrated pest management. HortTechnology 8:40-44.

Campbell, C.D., J.F. Walgenbach, and G.G. Kennedy. 1991. Effect of parasitoids on lepidopterous pests in insecticide-treated and untreated tomatoes in western North Carolina. J. Econ. Entomol. 84:1662-1667.

National Coalition of Integrated Pest Management. 1994. Toward a goal of 75 percent cropland under IPM by 2000 . Natl. Coalition Integrated Pest Mgt., Austin, Texas.

Pernezny, K., D. Schuster, P. Stansky, G. Simone, V. Waddill, J. Funderburk, F. Johnson, R. Lentini, and J. Castner. 1995. Florida tomato scouting guide with insect and disease identification keys. Univ. Fla. Coop. Ext. Serv. Inst. Food Agr. Sci. SP-22.

Pitblado, R.E. 1992. The development and implementation of TOM-CAST, p. 5-37. In: Proc. $7^{\text {th }}$ Annu. Tomato Dis. Wkshp., Toledo, Ohio, 6 Dec. 1991.

Sikora, E.J., E.M. Bauske, and J. Pitts. 1994a. Evaluation of fungicides using fixed and weather-timed spray schedules for early blight control of fresh market tomatoes. Fungicide and Nematicide Tests 49:173.

Sikora, E.J., E.M. Bauske, G.W. Zehnder, and M.H. Hollingsworth. 1994b. Evaluation of low-input fungicide spray programs for control of early blight on tomatoes. Auburn Univ. Agr. Expt. Sta. Highlights Agr. Res. 41:15.

Spittler, T.D., R.J. Argauer, D.J. Lisk, R.O. Mumma, G. Winnett, and D.N. Ferro. 1984. Gas chromatographic determination of fenvalerate insecticide residues in processed tomato products and byproducts. J. Assn. Off. Anal. Chem. 67:824-826.

USDA. 2001. Farm computer usage and ownership. USDA Natl. Agr. Stat. Serv. 12 Mar. 2002. <http://usda.mannlib.cornell.edu/ reports/nassr/other/computer/>

Zehnder, G.W., E.J. Sikora, and W.R. Goodman. 1995. Treatment decisions based on egg scouting for tomato fruitworm reduce insecticide use in tomato. Crop Protection 14:683-687. 